\title{
Biochemical and Morphological Aspects of Salivary Glands of the Predator Brontocoris tabidus (Heteroptera: Pentatomidae)
}

\author{
Dihego de Oliveira Azevedo ${ }^{1}$, José Cola Zanuncio ${ }^{2}$, José Salazar Zanuncio Jr. ${ }^{2}$, Gustavo \\ Ferreira Martins ${ }^{1}$, Solange Marques-Silva ${ }^{1}$, Marcos Franklin Sossai ${ }^{2}$ and José Eduardo \\ Serrão ${ }^{1}$ * \\ ${ }^{1}$ Departamento de Biologia Geral; ${ }^{2}$ Departamento de Biologia Animal; Universidade Federal de Viçosa; Av PH \\ Rolfs s/n; Campus Universitário; jeserrao@ufv.br; 36570-000; Viçosa - MG - Brasil
}

\begin{abstract}
The aim of this work was to study the feeding habits of the predator Brontocoris tabidus (Heteroptera: Pentatomidae) analyzing the salivary gland complex (SGC). The SGC was dissected and subjected to histological analyses and biochemical assays. Results showed that a pair of bilobed principal salivary glands and one pair of tubular accessory salivary glands form the SGC and different parts of salivary gland synthesizes similar substances. Lipases, $\alpha$-amylase and trypsin-like enzymes were detected at both lobes of the principal salivary gland. These data together with observations related to the predator's diet suggested that it could be considered an obligate zoophytophagous.
\end{abstract}

Key words: Salivary glands, biological control, Heteroptera, Pentatomidae

\section{INTRODUCTION}

In Brazil, large agricultural areas are cultivated with monocultures, which favors insect pests (Zanuncio et al., 1994b). Use of chemical products to control had caused damage to the environment and to man increasing the importance of natural enemies such as Heteroptera predators (Bueno and Berti, 1991; Zanuncio et al., 1994a) in programs of integrated pest management (Molina-Rugama et al. 1997, 1998).

Pentatomidae presents species with high potential to control insect pests such as those of Asopinae including Podisus maculiventris (Say) and Perillus bioculatus (F.) in North America and Europe, Podisus nigrispinus (Dallas) (Zanuncio et al., 2001) and Brontocoris tabidus (Signoret) (Zanuncio et al., 2000) in South America, and
Eocanthecona furcellata (Wolff) in the Southeast of Asia and India (De Clercq, 2000). Brontocoris tabidus presents attack mechanism consisting of stylet insertion in the prey body causing progressive paralysis, allowing feeding (J.C. Zanuncio, personal observation). Paralysis of prey is part of a typical feeding mechanism named extra oral digestion (EOD). It results from a chemical pretreatment to mobilize nutrients that will be later ingested, what is common for Heteroptera predators that feed on large prey (Cohen, 1995). EOD is a cyclical process, consisting of three phases: injection of toxins and/or digestive enzymes, initial digestion of the food and ingestion of the liquefied material (Cohen, 1993, 1995). Another important aspect of B. tabidus is its need of plant feeding that can improve some of their characteristics such as oviposition rate,

${ }^{*}$ Author for correspondence 
nymph development and survival (Zanuncio et al., 2000), what has also been reported for other Heteroptera (Saavedra et al., 1997; Zeng and Cohen, 2000; Boyd, 2003).

Toxins and/or digestive enzymes involved in EOD can be produced in specialized structures such as labial and maxillary glands or in the gut like in spiders and beetles. Toxins are difficult to be distinguished from digestive enzymes, because they can also act as enzymes (Cohen, 1995). The salivary gland complex is another structure that can produce substances necessary for nutrient mobilization, usually digestive enzymes, which can be used to characterize feeding habits of insects (Cohen, 1993; Zeng and Cohen, 2000; Boyd, 2003). The purpose of this study was to analyze the morphology of the salivary glands of the predator B. tabidus and the biochemical aspects of their content to contribute to the comprehension of the feeding habit of this natural enemy.

\section{MATERIALS AND METHODS}

Fifty adults of B. tabidus were obtained from a laboratory culture maintained on seedlings of Eucalyptus urophylla at $25 \pm 2{ }^{\circ} \mathrm{C}, 65 \pm 10 \% \mathrm{RH}$ and $13 \mathrm{~h}$ photoperiod, fed on Tenebrio molitor (Coleoptera: Tenebrionidae) pupae in the Insectary from Federal University of Viçosa, State of Minas Gerais, Brazil.

\section{Morphology}

Adults of B. tabidus were immobilized in ice and the salivary gland complex were dissected in cold saline solution $(\mathrm{NaCl} 125 \mathrm{mM})$. Salivary glands from 15 insects were transferred to Zamboni's fixative solution (Stefanini et al., 1967) and dehydrated in ethanol series, embedded in glycol metacrylate historesin JB4 (Polyscience) and cut in $5 \mu \mathrm{m}$ thin slices for analysis under light microscope. Sections were stained with haematoxylin and eosin, or submitted to the following histochemical test: mercurybromophenol blue for total proteins, PAS for neutral polysaccharides and glycoconjugates and Nile blue for acid lipids (Pearse, 1980).

Some pieces after fixation were dehydrated in ethanol series, transferred to hexamethyldisilazane (HMDS) for $5 \mathrm{~min}$, air dried and gold covered.
The samples were analyzed under scanning electron microscope JEOL VP 30X.

\section{Protein determination and SDS-PAGE}

The glands extracted from the other 35 insects were separated in the anterior lobe, posterior lobe and accessory gland and homogenized in saline solution with the aid of a Potter. Crude homogenates were centrifuged at $10000 \mathrm{~g}$ for 20 min resulting in a supernatant used as gland soluble fraction. Protein was determined according to Bradford (1976) using ovalbumin as standard. Extracts were used for analysis in SDS-PAGE and for enzyme's assays.

SDS-PAGE of samples was carried out in $12 \%$ $(\mathrm{w} / \mathrm{v})$ polyacrylamide gels containing $10 \%(\mathrm{w} / \mathrm{v})$ SDS on a discontinuous $\mathrm{pH}$ system (Laemmli, 1970) using Mini-protean 3 cell equipment (BIORAD). Samples were mixed with sample buffer (1:2) containing $0.5 \mathrm{M}$ Tris- $\mathrm{HCl}, \mathrm{pH} 6.8,10 \%$ $(\mathrm{w} / \mathrm{v})$ SDS, $0.71 \mathrm{M} \quad \beta$-mercaptoethanol, 25\% glycerol and $0.5 \%(\mathrm{w} / \mathrm{v})$ bromophenol blue and boiled for four minutes at $95{ }^{\circ} \mathrm{C}$ in a water before being loaded onto the gels. Electrophoresis was carried out at $150 \mathrm{~V}$ and the gel was silver-stained for proteins (Blum et al., 1987). Molecular-weight markers used were: lysozyme $(14.4 \mathrm{kDa})$, soybean trypsin inhibitor $(21.5 \mathrm{kDa})$, carbonic anhydrase (31 kDa), ovalbumin (45 kDa), bovine serum albumin $(66.2 \mathrm{kDa})$, and phosphorylase b (97.4 kDa) (BIO-RAD cat. N. 161-0304).

\section{Enzymes}

Samples from anterior and posterior lobes were submitted to enzymes assays. The activity of the $\alpha$-amylase and lipase was determined with Bioclin kits (Quibasa). Trypsin-like (EC 3.4.21.4) was determined using $0.5 \mathrm{mM}$ BapNA in $0.1 \mathrm{M}$ Tris$\mathrm{HCl}, \mathrm{pH} 8.2$ containing $20 \mathrm{mM} \mathrm{CaCl} 2$ and $1 \%$ dimetylformamide (v/v) (Erlanger et al., 1961). The activity was determined by the formation of the product p-nitroaniline, measured at $410 \mathrm{~nm}$ as function of time (5 $\mathrm{min}$ ) using the extinction molar coefficient $8800\left(\mathrm{M}^{-1} \mathrm{x} \mathrm{cm}^{-1}\right)$ for the activity's final calculations.

\section{RESULTS}

\section{Anatomy}

The salivary gland complex of B. tabidus was formed by one pair of principal salivary glands 
with two lobes and one pair of tubular accessory glands (Figs. 1, 2). Salivary glands were located in the prothoracic region projecting forward to the head and backwards until the mesothorax. They were seen as enlarged sacs with shaped ends. There was a strong constriction in the 1/5 anterior portion forming two glandular lobes. The anterior lobe was shorter than the posterior, presenting the terminal process in its final portion (Figs. 3, 4). Two ducts were placed in the constriction region. The gland duct was short and extended to the head of the predator where it fused near the stylet with the other gland duct coming from the other principal salivary gland. The other duct in the salivary gland constriction aroused from the salivary accessory gland. This duct was long and extended to the mesothorax, with many U-shaped folds until $2 / 3$ of its length, where it extended forward to the head and back to the thorax. It became enlarged in the final portion, forming the tubular accessory salivary gland with the end linked to the posterior lobe of the principal salivary gland via a fine trachea (Figs. 1,2).
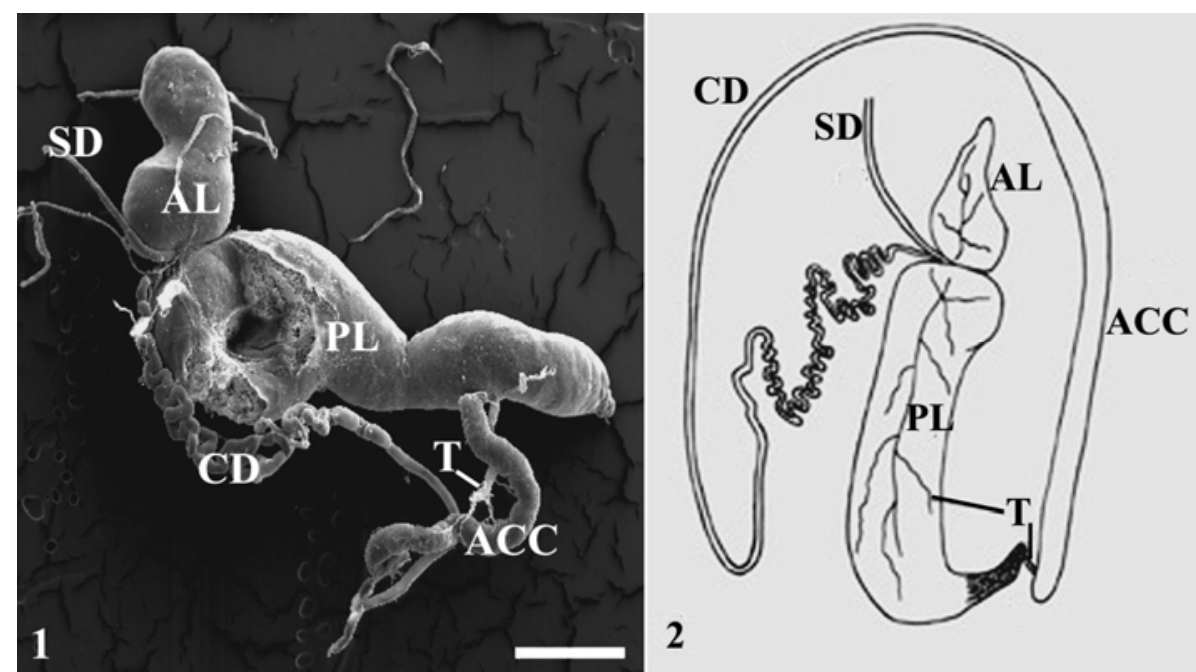

Figures 1 and 2 - Salivary system of Brontocoris tabidus: 1, scanning electron micrograph. Bar = $200 \mu \mathrm{m} ; 2$, schematic draw. ACC - accessory salivary gland; AL - anterior lobe; PL - posterior lobe; CD - duct of accessory gland; SD - salivary duct; T trachea; Not drawn with scale.

\section{Histology of the accessory salivary gland}

The accessory salivary gland presented a widened secretory portion formed by a single layered epithelium with secretory cells varying from cubic to prismatic shape, covered by a thin cuticle (3.3 $\mu \mathrm{m})$ lining a narrow lumen without storage of substances (Figs. 5, 6). The secretory cells had nuclei in basal region with a granulated aspect of the chromatin. Some cells had two nuclei, but all of then had a well-developed nucleolus (Fig. 6). The cytoplasm was strongly basophile in the basal region and it was characterized by granules of different sizes and filled with a few basophile content that could be seen as longitudinal grooves under low resolution (Figs. 5, 6).

The secretory cells presented weak positive reaction for PAS, mercury-bromophenol blue
(Figs. 8, 9) and absence of reaction to Nile blue. The duct's cells of the accessory gland were flattened with pleomorphic nucleus with a more condensed chromatin than that on secretory cells (Fig. 7). The apex of these cells had many folds while the cuticle was thick $(13.6 \mu \mathrm{m})$ and the portion in contact with the cell surface was strongly basophilic (Fig. 7) with taenidea presenting a radial aspect.

\section{Histology of the principal salivary gland}

The cuticle coating the lumen of the principal salivary gland of $B$. tabidus was not present. The secretion in the lumen of the anterior lobe was liquid, homogeneous and weakly acidophil (Fig. 10) with strong positive reaction to mercurybromophenol blue and PAS (Figs. 11, 12). 


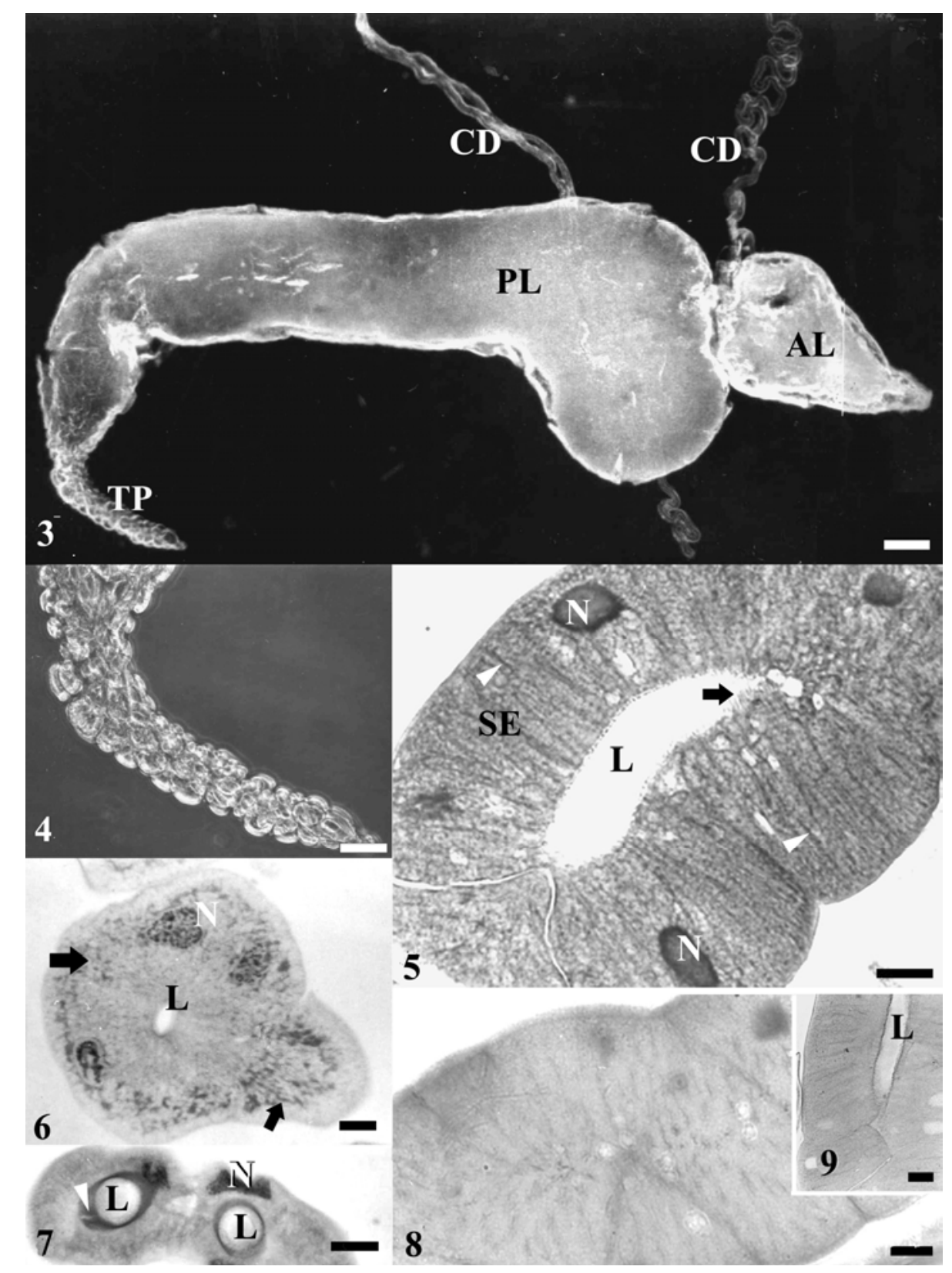

Figures 3 to 9 - Salivary system of Brontocoris tabidus: 3, general view showing the anterior (AL) and posterior lobes (PL). CD - duct of accessory gland; TP - terminal process. Bar $=0.5 \mathrm{~mm} .4$, details of terminal process. Bar $=100 \mu \mathrm{m} .5$, longitudinal section of accessory salivary gland showing secretory epithelium (SE), constituted by cells with longitudinal grooves (arrowheads) and a thin cuticle (arrow) lining the empty lumen $(\mathrm{L})$. Bar $=50 \mu \mathrm{m} .6$, transversal section of salivary accessory glands showing basophilic basal cytoplasm (arrows) and the nucleus with granular chromatin $(\mathrm{N})$. Bar $=50 \mu \mathrm{m} .7$, duct of salivary accessory gland showing flattened cells with pleomorphic nucleus $(\mathrm{N})$ and the basophilic cuticle lining the lumen $(\mathrm{L})$. Bar $=50$ $\mu \mathrm{m} .8$, mercury-bromophenol blue staining showing weak reaction in the accessory salivary gland. Bar $=50 \mu \mathrm{m}$. 9, PAS reaction showing weak reaction in the accessory salivary gland epithelium. Bar $=50 \mu \mathrm{m}$. 
The epithelial (secretory) cells were flattened with elongated nuclei containing condensed chromatin when the gland lumen was filled (Fig. 10). On the other hand, the epithelial cells were cubic with rounded, or oval nuclei containing chromatin as minute granules and with 1-2 nucleoli when there was few secretions in the lumen. Secretory cells reacted positively to mercury-bromophenol and weakly to PAS.

Externally, there was a peritoneal sheath constituted of flat cells with elongated nuclei showing condensed chromatin. The secretion and secretory cells showed negative reaction to Nile blue.

The secretion in the lumen of the posterior lobe had a gelatinous consistence and it was acidophilus with granules of different sizes (Fig. 10), presenting weak reaction to PAS and to mercury-bromophenol blue (Figs. 11, 12) and negative reaction to Nile blue. A single layer of cubic secretory cells with basophilic apex formed the epithelium (Fig. 13). The nucleus was well developed containing chromatin with aspect of minute granules and large nucleolus. The secretory cells were positive to mercury-bromophenol and to PAS (Figs. 11, 12). The peritoneal sheath was similar to that of the anterior lobe.

\section{Proteins}

The total protein content was $0.21 \mu \mathrm{g} / \mu \mathrm{L}$ in the anterior lobe, $0.13 \mu \mathrm{g} / \mu \mathrm{L}$ in the posterior lobe and $0.16 \mu \mathrm{g} / \mu \mathrm{L}$ in the accessory gland. SDS-PAGE of both lobes of the principal salivary gland's extracts showed the presence of 13 polypeptides, with one of them exclusive of the posterior lobe, five of the anterior one, and seven common to both (Fig. 14). Six polypeptides with $\mathrm{Mr}<60 \mathrm{kDa}$ were found in the accessory gland but none of them was found in the lobes of the principal salivary gland (Fig. 14).

\section{Enzymes}

Trypsin-like activity was detected in both lobes of the principal salivary gland with similar values between them (Table 1). Amylase activity was also detected in both lobes however with higher activity in the anterior than in the posterior lobe, while lipase activity was higher in the posterior lobe (Table 1).

\section{DISCUSSION}

The anatomical pattern of the salivary system of $B$. tabidus, with a pair of principal glands with two lobes and another of tubular accessory glands was similar to that found in others predators and plantsucking Pentatomidae (Baptist, 1941; Kamaluddin and Ahmad, 1992). Baptist (1941) described a terminal process in the final area of the posterior lobe, with cells different from those of the secretory epithelium of the lobes. However, this difference in the cells could be an artifact and the same cell type formed the whole lobe. The terminal process (Figs. 2, 3) could not be characterized when the glands were dissected directly in the fixative, while in those removed in saline solution it appeared, suggesting that it resulted from osmotic problems.

The anatomical and histochemical results of the accessory salivary gland of $B$. tabidus suggested that their cells might be involved in the secretion of substances and in the transport of others from the haemolymph. This was reported for Poecilometis punctiventris (Heteroptera: Pentatomidae) (Stål) whose accessory salivary gland was responsible for the aqueous part of the saliva although it transported large proteins about $40 \mathrm{kDa}$ from haemolymph to the glandular ducts (Miles and Slowiak, 1970, 1976). Tubular accessories glands of Heteroptera, or their ducts could present secretory activity (Baptist, 1941). The presence of exclusive proteins was shown in the accessory salivary gland of $B$. tabidus by SDSPAGE, some with $\mathrm{Mr}>40 \mathrm{kDa}$. These proteins should be those soluble in the lumen and in the duct of the gland and/or peripheral proteins from the plasma membrane of the secretory cells, because the extraction procedure was mild.

Muscle layers associated to the lobes were not found in the principal salivary glands, which differed from that observed for the glands on other predatory Heteroptera (Baptist, 1941) where a muscle sheath might be important to mobilize great amounts of saliva. This indicated that the saliva of $B$. tabidus cold be injected into the prey by extrinsic muscles. 


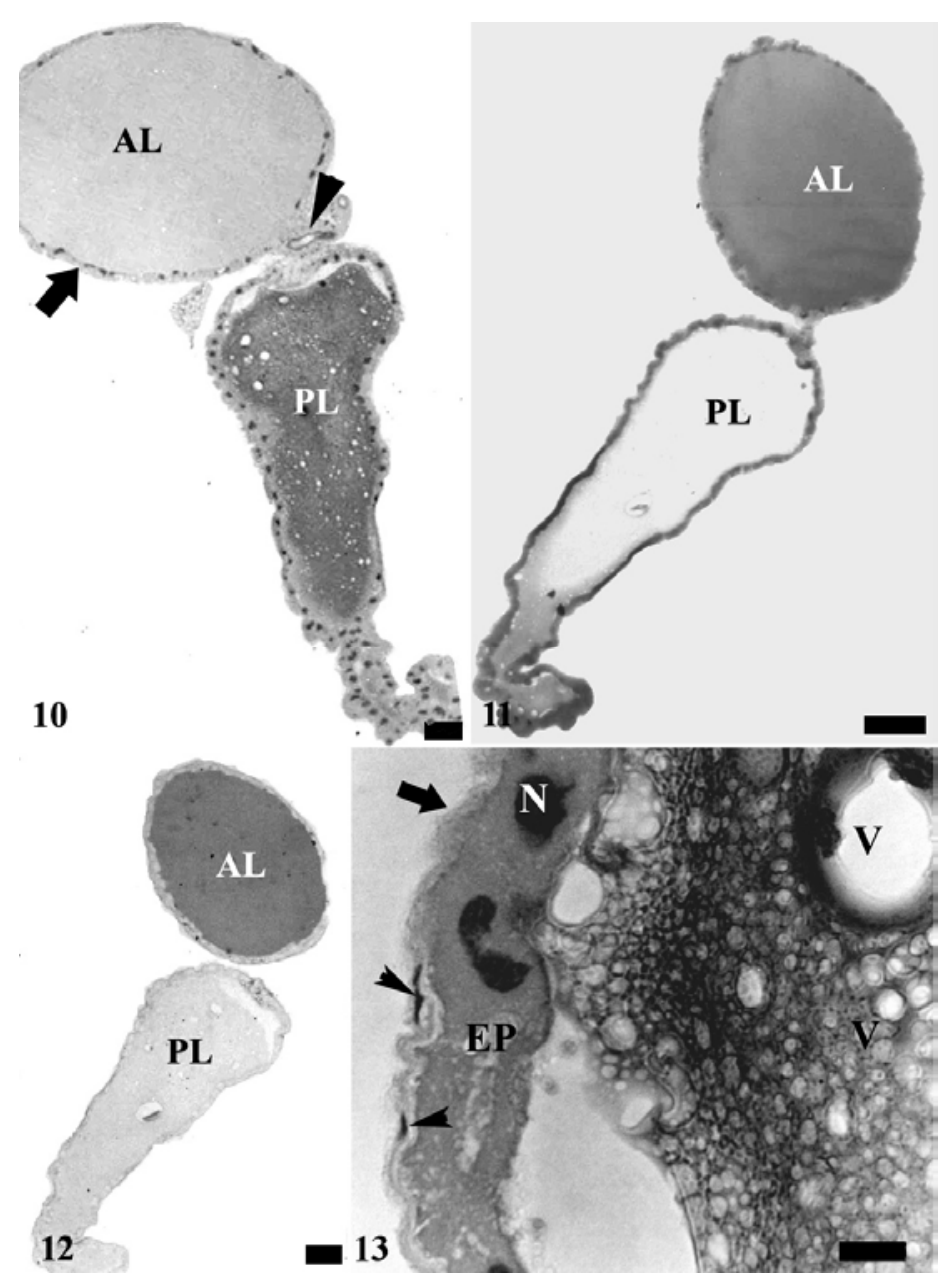

Figures 10 to 13 - Principal salivary glands of Brontocoris tabidus: 10, longitudinal section showing the anterior lobe (AL) filled with a homogeneous content almost unstained, while the posterior lobe (PL) has an acidophilus content with vacuolized aspect. Notice flattened epithelium (arrow) in the anterior lobe and the beginning of salivary duct (arrow head) in the constriction between both lobes. Bar $=100 \mu \mathrm{m}, 11$, mercury-bromophenol blue test showing positive reaction in the anterior lobe (AL) and a weak reaction in the posterior lobe (PL). Bar $=100 \mu \mathrm{m} ; 12$, PAS test showing positive reaction in the anterior lobe (AL) and absence of reaction in the posterior lobe $(\mathrm{PL})$. Bar $=100 \mu \mathrm{m} ; 13$, longitudinal section of the posterior lobe showing cubic epithelium (EP) and the well developed nucleus (N). Notice the vacuoles in the gland content and the thin peritoneal sheath (arrow) formed by flattened cells (arrowhead). Bar $=10 \mu \mathrm{m}$.

Table 1 - Enzyme activities in the principal salivary glands of B. tabidus.

\begin{tabular}{cccc}
\hline Gland region & Amylase (UI) & $\begin{array}{c}\text { Trypsin-like } \\
(\mathbf{x ~ 1 0} \mathbf{~ M / s})\end{array}$ & Lipase (UI) \\
\hline Anterior lobe & 93.6 & 2.671 & 4.0 \\
Posterior lobe & 77.2 & 2.619 & 13.2 \\
\hline
\end{tabular}




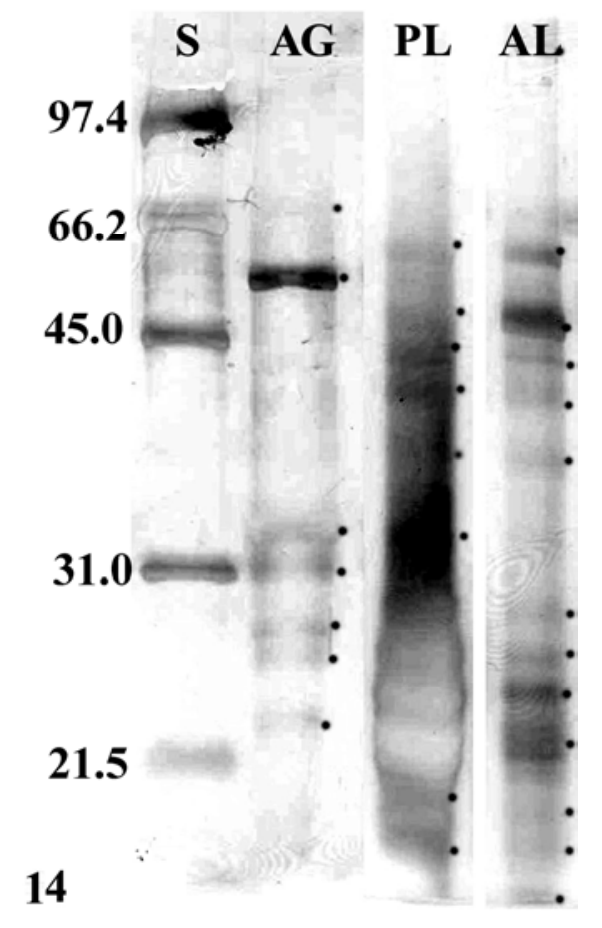

Figure 14 - SDS-PAGE of proteins of salivary gland complex of Brontocoris tabidus. Lane S molecular weight markers. Lane AG - accessory salivary glands. Lane PL - posterior lobe of principal salivary glands. Lane AL - anterior lobe of principal salivary glands. Dots show the proteins revealed by silver staining. Note there are different bands among the lanes, showing that each structure of salivary gland complex produces different proteins.

Histological data showed that many proteins of principal salivary glands were glycoproteins. SDSPAGE indicated that many of them were similar in both lobes, agreeing with Baptist (1941) who pointed out that different lobes of the salivary glands of Hemiptera released similar substances. The detection of amylase, lipases and trypsin-like activities in both lobes of the principal salivary glands of B. tabidus confirmed this hypothesis.

Enzymes of the principal salivary glands showed that $B$. tabidus could be characterized as an obligatory predator, but since this insect presented better development with plant and prey, it could be considered as an obligatory zoophytophagous. Some Heteroptera predators use amylase of their salivary glands to obtain energy from the starch of plant tissues and, in this case, they can be agricultural pests (Zeng and Cohen, 2000 and Boyd, 2003). Brontocoris tabidus may not use starch from plant tissues but only nutrients from sap such as plant-sucking Hemiptera. Bombyx mori L. (Lepidoptera: Bombyidae) larvae obtain substances such as methyl and ethyl aminoesters from the sap of mulberry leaves as stimulants of amino acids absorption in the midgut (Giordana et al., 2002). Brontocoris tabidus may also obtain other substances besides nutrients such as small sugars from plants. Therefore, the amylase of the principal salivary gland of this predator may be involved in the glycogen mobilization of their prey.

The toxicity of the saliva of Heteroptera predators is due to digestive enzymes (Baptist, 1941). The prey paralysis may result from damage by certain digestive enzymes in neurons, muscles and storage tissues of the prey. Structural proteins are hydrolyzed and liquefied inside the prey by endopeptidases such as trypsin-like injected by the predator, while cell membranes, storage tissues and reproductive systems are affected by phospholipases, triacylglicerol lipases and $\alpha$ amilase. Later, the hydrolyzed material is ingested with other nutrients from the prey and additional processing occurs in the gut allowing its 
absorption by the predator (Cohen, 1993, 1995). Besides, there are no reports of poisons used by Heteroptera during feeding.

Brontocoris tabidus does not present potential to be a crop pest, although it needs plants in its diet. Besides, the wide variety of digestive enzymes suggest that this species can feed on many preys, what increases its importance on population stabilization of different insect pests in the field.

\section{ACKNOWLEDGEMENTS}

We are grateful to Brazilian research agencies CNPq and FAPEMIG and to Prof. Dra. M. G. A. Oliveira for help in enzymatic analyses.

\section{RESUMO}

Esta pesquisa contribui para a compreensão dos hábitos alimentares do percevejo predador Brontocoris tabidus (Heteroptera: Pentatomidae) por meio de análises morfológicas e bioquímicas de suas glândulas salivares. Espécimes tiveram o sistema salivar dissecado, e parte das amostras obtidas foi submetida a análises histológicas. Secções foram coradas com hematoxilina e eosina ou submetidas aos testes histoquímicos azul de bromofenol, PAS e azul do Nilo. A outra parte das amostras dissecadas teve seu conteúdo analisado em SDS-PAGE e em ensaios de atividade enzimática. Os resultados mostram que o sistema salivar de B. tabidus é formado por um par de glândulas bilobadas principais e um par de glândulas tubulares acessórias, e que suas diferentes regiões sintetizam substâncias semelhantes. Os ensaios enzimáticos detectaram atividade para tripsina, amilase e lipase, que juntamente com observações de laboratório relativas à dieta do predador indicam que o mesmo pode ser considerado um zoofitófago obrigatório.

\section{REFERENCES}

Baptist, B.A. (1941), The morphology and physiology of the salivary glands of Hemiptera-Heteroptera. Quart Jour of Micr Sci, 83, 91-139.

Blum, H.; Beier, H.; Gross, H.J. (1987), Improved silver staining of plant proteins, RNA and DNA in polyacrylamide gels. Eletrop, 8, 93-99.
Boyd, D.W.Jr (2003), Digestive enzymes and stylet morphology of Deraeocoris nigritulus (Uhler) (Hemiptera: Miridae) reflect adaptations for predatory habits. Ann Entom Soc Am, 96, 667-671.

Bradford, M.M. (1976), A rapid and sensitive method for the quantitation of microgram quantities of protein utilizing the principle of protein-dye binding. An Biochem, 72, 248-254.

Bueno, V. H. P.; Berti Filho, E. (1991), Controle biológico de insetos com predadores. Inf Agropec, 15, 41-52.

Cohen, A. C. (1993), Organization of digestion and preliminary characterization of salivary trypsin-like enzymes in a predaceous heteropteran Zelus renardii. J Insect Physiol, 39, 823-829.

Cohen, A. C. (1995) Review: Extra-oral digestion in predaceous terrestrial arthropod. Ann Rev Entomol, 40, 85-103.

De Clercq, P. (2000), Predaceous stinkbugs (Pentatomidae: Asopinae). In Schaefer, C.W. and A.R. Panizzi, Heteroptera of Economic Importance. $1^{\circ}$. ed. Cambridge: Cambridge University, p. 737-789.

Erlanger, B. F.; Cohen, W.; Kokowsky, N. (1961), The preparation and properties of two new chromogenic substrates of trypsin. Arch. of Bioch. and Bioph, 95, 271-278.

Giordana, B.; Casartelli, M.; Fiandra, L.; Forcella, M.; Hanozet, G.M.; Leonardi, M.G.; Parenti, P. (2002), A novel regulatory mechanism for amino acid absorption in lepidopteran larval midgut. $J$ Insect Phys, 48, 585-592

Kamalludim, S.; Ahmad, I. (1992), Internal anatomy and histology of alimentary organs, salivary apparatus and reproductive organs of Megarrhamphini, Phyllocephalini and Tetrodini (Hemiptera: Pentatomidae: Phyllocephalinae) and their bearing on classification. Philip Jour of Sci, 121, 129-156.

Laemmli, U. K. (1970), Cleavage of structural proteins during the assembly of the head of bacteriophage $\mathrm{T}_{4}$. Nature, 227, 680-685.

Miles, P. W.; Slowiak, D. (1970) Transport of whole protein molecules from blood to saliva of a plant-bug. Exper, 26, 611-612.

Miles, P. W.; Slowiak, D. (1976) The accessory salivary gland as the source of water in the saliva of Hemiptera: Heteroptera. Exper, 32, 1011-1012.

Molina-Rugama, A. J.; Torres, J. B.; Zanuncio, J. C.; Zanuncio, T. V. (1997), Longevidad y fecundidad de Podisus nigrispinus (Heteroptera: Pentatomidae) alimentado com Musca domestica (Diptera: Muscidae) y frijol. Rev Biol Trop, 45, 1125-1130.

Molina-Rugama, A. J.; Cruz, I.; Pratissoli, D.; Zanuncio, J. C. (1998), Efeito do intervalo de alimentação na reprodução e na longevidade do predador Podisus nigrispinus (Dallas) (Heteroptera: Pentatomidae). An Soc Entomol Brasil, 27, 77-84. 
Pearse, A. G. E. (1980), Histochemistry Theoretical and Applied. Vol 1, Preparative and Optical Technology. $4^{\text {th }}$ ed. Churchill Livingstone, Edinburgh.

Saavedra, J. L. D.; Guedes, R. N. C.; Zanuncio, J. C.; Zanuncio, T. V. (1997), Prey capture ability of Podisus nigrispinus (Dallas) (Heteroptera: Pentatomidae) reared for successive generations on a meridic diet. Jour Appl Entom, 121, 327:330.

Stefanini, M.; Demartino, C.; Zamboni L. (1967), Fixation of ejaculated spermatozoa for electron microscopy. Nature, 216, 173-174.

Zanuncio, J. C.; Garcia, J. F.; Nascimento E. C.; Zanuncio, T. V. (1994a), Major lepidopterous defoliators of eucalypt in southeast Brazil. For Ecol and Manag, 65: 53-63.

Zanuncio, J. C.; Alves, J. B.; Garcia, J. F.; Zanuncio, T. V. (1994b), Hemipterous predators of eucalypt desfoliators caterpillars. For Ecol Manag, 65, 65-73.
Zanuncio, J. C.; Guedes, R. N. C.; Ramalho, F. S.; Zanuncio T. V. (2000), Effect of feeding on three Eucalyptus species on the development of Brontocoris tabidus (Het.: Pentatomidae) fed with Tenebrio molitor (Col.: Tenebrionidae). Bioc Sci Technol, 10, 443-450.

Zanuncio, J. C.; Molina-Rugama, A. J.; Pratissoli, D; Serrão, J. E. (2001), Nymphal development and reproduction of Podisus nigrispinus (Heteroptera: Pentatomidae) fed with combinations of Tenebrio molitor (Coleoptera: Tenebrionidae) pupae and Musca domestica (Diptera: Muscidae) larvae. Bioc Sci Techn, 11, 331-337.

Zeng, F.; Cohen, A. C. (2000), Comparison of $\alpha$ amilase and protease activities of a zoophytophagous and two phytozoophagous heteroptera. Comp Bioch Phys, 126, 101-106. 
PÁGINA

EM

BRANCO 